\title{
CONTRIBUTIONS TO THE BIOLOGY OF FRESHWATER FISHES
}

\author{
By W. RUBHTON, A.R.C.8., D.I.C., F.L.8. \\ I. THE EFPECTS OF VARIOUS MMPURITIES IN A BTREAM ON \\ THE LIHE OF SPERMATOZOA OF TROUT AND YOUNG TROUT
}

AT the suggestion of the owner of a salmon and trout stream in Banf: shire, which of late years has become very polluted owing to variow trade products, a series of experiments was undertaken to find out whether the various trade wastes have any effect on the fertilising powe of the spermatozos.

The method adopted was to have crude samples of every type of trade effluent collected when at its worst and delivered in London. On receipt of it the milt and ova were extracted from fully mature fish, and submitted to the various effluents in order to test the power of fertiliention in the presence of the impurity. When the milt and ore had been in contact a certain length of time the ova were placed in an artificial redd in running water and the number of eggs which hatched out and gave rise to normal embryos noted.

The whole of the work had to be done between Deceimber and March of the following year, as it is only in the late fall that fartile fish are obtainable. The trade effluents of the particular stream under consideration are waste products from aix distilleries, consisting of spent malt products and yeast cells from the first distillations. Effluent from a tweed mill where wool-scouring, dyeing and weeving are carried on, and crude sewage from the town.

The effluent samples were collected as far as possible just as they were entering the stream except in the case of the cloth mills where this was impossible, owing to the mill standing over the stream, and only a diluted sample was obtainable.

The method of obtaining the ripe ova was to take mature brown trout and, after drying the fish as far as possible, by gentle pressure to extract the eggs into a clean dish; the same procedure was adopted in regard to the milt, great care being taken to prevent water mixing with 
either milt or eggs till the two were brought in contact in the presence of the effluent under examination.

Ten eggs were taken up in each case and submitted to the various effluents with a measured quantity of milt and the two left in contact for 30 minute to ensure uniformity throughout.

Some of the milt was examined microscopically at the same time and the length of time before activity ceased was noted.

It is known that the milt of trout will remain in good condition and fertilise ova 24 hours after extraction if kept free from moisture, i.e. if care is taken in extraction that no drainings or drippings from the male fish are allowed to come in contact with it; but if brought in contact with water they at once become very active and lose their fertilising power after three minutes' activity so that the period of activity is very short. This experiment can easily be done by taking a series of drops of milt on a slide side by side and adding the smallest drop of water to each and the time of activity taken.

It is further known that some spermatozas of fish are more sensitive to poisons than young or mature fish and may be killed by such amall amounts of poisons as can be detected only by very refined chemical methods.

Sample 1. Water from the upper reaches of the stream before any effluent had entered.

Colour $\quad \ldots . \quad$... None.

Reaction ... ... Neutral cold or hot using phenol-phthalein indicator.

Activity of sperms Three minutes.

Eiggs all fertilised and gave rise to normal embryos 90 per cent. of which hatched. One year and one two-year-old trout remained alive in this sample for over a woek when they were removed to freeh water.

Sample 2. Containing effluent from one distillery.

Colour ... ... None.

Resction ... ... Neutral hot or cold.

Sperms ... ... Active for 2 to 3 minutes.

Eggs all fertilised and gave rise to normal embryos 90 per cent. of which hatched out.

Sample 3. Diluted sample from a woollen mill where wool-scouring takes place.

Colour $\quad \ldots . \quad \ldots$ Slightly yellow.

Reaction ... ... Neutral cold, alkaline hot.

Spermas ... ... Active 2 minutea. 


\section{C'untributions to the Biology of Freshwater Fishes}

Ova fertilised and gave rise to normal embryos; 85 . per cent. hatehed out.

Sample 4. From same place as 3, but taken a few hours later; similar results to 3 , but sample a little more alkaline. Two yearling trout introduced into these samples, although they showed uneasiness at first, soon settled down to the unusual conditions and were alive four weeks afterwards and during the period showed no unusual symptoms.

Sample 5. Taken from below the sewage outflow after crude sewage had entered the stream.

$$
\begin{array}{llll}
\text { Colour } & \ldots & \ldots & \text { Yellow. } \\
\text { Reaction } & \ldots & \ldots & \text { Neutral cold, alkaline hot. } \\
\text { Sperms } & \ldots & \ldots & \text { Lived only 1.75 minutes. }
\end{array}
$$

Ova fertilised and gave rise to normal embryos in fresh water in four cases only. The effect on yearling fish was very marked with this sample. As soon as the fish were introduced they showed signs of trouble at once. The jaws began to move actively, attempts at lesping out of the liquid were very frequent, then after 5 minutes a period of rest at the bottom of the vessel, the fish appearing to be exhausted, then further attempts at coming to the surface were made with gradual sinking to the bottom again. This continued for 15 minutes, when the fish showed signs of turning on their sides and within a few seconds were on their backs. Then spasmodic darts took place in an aimless manner which continued periodically for about an hour when the fish died.

Repeating this experiment but removing to fresh water at the first signs of turning over it was found possible to recover them and in a few days they acted quite normal.

Diluting this sample 1 in 4 the period of being overcome was lengthened, but the final result was the same.

Sample 6. This was from the same source as 5 , but taken from the outflow pipe before it entered the stream.

Analysis of this sample showed it to be crude sewage.

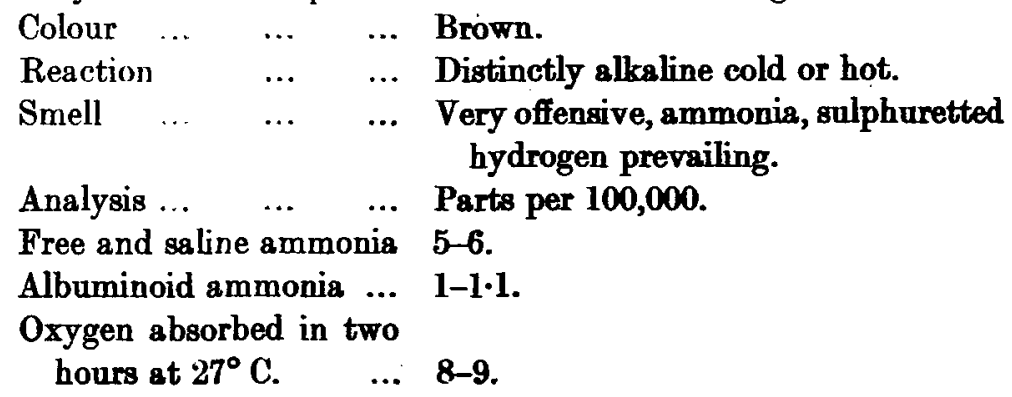


Sample shaken up showed froth at top which remained for 24 hours before disappearing (in a purified sample froth should disappear in three minutes). Sperms were active in this sample for one minute only. Ova fertilised in this crude sewage and removed to fresh water gave normal embryos, only four hatching out.

Yearlings placed in this sample would not live more than 5 minutes and throughout the period of emersion were in a violent state of activity.

Sample 7. This was a sample taken from the effluent pipe from a distillery when a full discharge was taking place.

A large amount of suspended colloidal matter was present which microscopic examination showed to be broken-down yeast cells and starch grains, some in an unbroken condition and others much broken up. The whole was of a whitish colour with a large amount of finely suspended matter very like starch paste.

The cloudiness took several days to dissppar on standing when a mass of fungal hyphae appeared on the battom.

Reaction $\quad \ldots \quad \ldots$ Slightly acid cold; neutral hot.

Tested for presence of $\mathrm{CO}_{2}$ showed a large amount present. Milt and ova were not available when this sample was taken and only its effects on yearling trout was ascertained.

This was peculiar, for almost as soon as introduced the fish became very sleepy, remaining at the bottom of the vessel till finally overcome within an hour and if left half an hour longer died.

Repeating this experiment but removing to fresh water at the end of an hour, when first overcome, the fish recovered its normal position within 10 minutes, indicating that crude distillery waste puts fish out of action probably through the excess of $\mathrm{CO}_{2}$ present and the deficiency of free oxygen. This experiment has been repeated using freshly drawn distillery wash from a London distillery and the same effect obtained.

The amount of oxygen in solution rarely reached more than 2 c.c. per litre against a normal 6-7. Well aerating a sample of distillery wash improved matters especially after standing for some time to allow the colloidal matter to settle out. The addition of lime water or powdered lime helped to improve the liquor so that it was able to support fish-life if most of the $\mathrm{CO}_{2}$ was removed and oxygen introduced. 


\section{Contributions to the Biology of Freshwater Fishes}

\section{Summary of Results.}

\begin{tabular}{|c|c|c|c|c|c|c|}
\hline Sample & Colour & Reaction & Debris & $\begin{array}{l}\text { Life of } \\
\text { sperms } \\
\text { mins. }\end{array}$ & $\begin{array}{l}\text { Effect on } \\
\text { fiah }\end{array}$ & Romarks \\
\hline 1. Pure water & None & Neutral & None & 3 & Unaffected & $90 \%$ eggs hatched out \\
\hline $\begin{array}{l}\text { 2. Diluted distillery } \\
\text { effluent }\end{array}$ & None & $\begin{array}{c}\text { Hot or cold } \\
\text { neutral }\end{array}$ & None & $2-3$ & " & 1 distillery, $90 \%$ eggs \\
\hline $\begin{array}{l}\text { 3. Diluted woollen } \\
\text { mill effluent }\end{array}$ & $\begin{array}{l}\text { Slightly } \\
\text { yellow }\end{array}$ & $\begin{array}{l}\text { Neutral cold, } \\
\text { alkaline hot }\end{array}$ & $\begin{array}{c}\text { Small } \\
\text { amount }\end{array}$ & $2 \cdot 0$ & $\begin{array}{l}\text { Slightly } \\
\text { sffected }\end{array}$ & $85 \%$ hatched out \\
\hline $\begin{array}{l}\text { 4. Diluted woollen } \\
\text { mill effluent }\end{array}$ & $\begin{array}{l}\text { Slightly } \\
\text { yellow }\end{array}$ & $\begin{array}{l}\text { Alkaline, } \\
\text { hot or cold }\end{array}$ & $\begin{array}{l}\text { Small } \\
\text { smount }\end{array}$ & $\mathbf{2 \cdot 0}$ & Unoasiness & $85 \%$ hatched out \\
\hline 5. Sewage & Yellow & $\begin{array}{l}\text { Neutral cold, } \\
\text { alkaline hot }\end{array}$ & $\begin{array}{l}\text { Small } \\
\text { amount }\end{array}$ & $1 \cdot 75$ & Fatal & $\begin{array}{l}\text { Contained large percent- } \\
\text { age sewage }\end{array}$ \\
\hline 6. Crude sewage & Brown & $\begin{array}{l}\text { Alkaline cold, } \\
\text { alkaline hot }\end{array}$ & $\underset{\text { Small }}{\text { Smount }}$ & 1.0 & Fatal & $\begin{array}{l}\text { Very offengive, putrid } \\
\text { smell, } 40 \% \text { egggs } \\
\text { hatched out }\end{array}$ \\
\hline $\begin{array}{l}\text { 7. Crude distillery } \\
\text { waste }\end{array}$ & Whitish & $\begin{array}{c}\text { Slightly acid } \\
\text { cold, neutral } \\
\text { hot }\end{array}$ & $\begin{array}{c}\text { Small } \\
\text { amount }\end{array}$ & - & Fatal & $\begin{array}{l}\text { Contained a lot of col } \\
\text { loidal matter, burs } \\
\text { yeast and starch grai }\end{array}$ \\
\hline
\end{tabular}

Field-work was done in the area from which the samples were drawn to determine how far the laboratory experiments agreed with the conditions present.

The distillery effluent has a very marked effect on the bed of the stream.

A very small tributary of the main stream on the banks of which only one distillery is present was selected.

Above the distillery the water was clear and fish were abundant, below the distillery for about a mile no fish were found. The distillery effluent is allowed to settle a little but reaches the stream as a yeastcoloured liquid. The stream is coloured a short distance below outflow and as the debris settles a filamentous fungus appears covering the stones with a grey flocculent growth.

The species of fungus was not determined but it covers the stones for over a mile down the stream when it gradually thins out where the stream becomes normal again and fish appear. When the fungus has fructified it turns black and gives rise to a black slimy mud of a very offensive nature and makes the stream look black.

The distillery effluent contains a large amount of nitrogen from the yeast and barley and unused up starch grains. Below the woollen mill no fish were present on account of the high alkalinity which prevails at times together with waste dye-stuffs. The crude sewage gives rise to fungal growths very similar to that from the distilleries, but in less amounts. 


\section{Conclusions.}

1. That distillery effluent and crude sewage is detrimental to the life of sperms and fish if poured into a stream untreated.

2. That the contents of distillery effluent give rise to fungal growths, preventing algal and flowering plants from growing and aerating the water.

3. That the plant and animal life of a stream is affected by crude trade wastes and untreated sewage entering it.

\section{BIOLOGICAL PROBLEMS CONNECTED WITH A TROUT FARM}

Bome two years ago my attention was drawn to a serious trouble, which froquently occurs in the rearing of trout for re-stocking streams, at a trout farm in the south of Scotland; and as a result of the investigation appeared to be of economic importance, it was thought worth while to record it.

The disease is one only found in northern areas and known as "Bloom." It attacks young fry a few weeks after hatching when the food-sac is all used up and artificial feeding has begun. Often the disease continues all through the summer, only fry which are mildly attacked murviving.

The attack takes the form of a bluish appearance, arising on the flanks of the fish just behind the gill covers, gradually extending backwards towards the tail, during which time the fish get perceptably thinner and ultimately succumb a few weeks after the first attack.

The hatchery in question is served by two streams from which raceways direct the water to the various parts of the farm. Both streams drain uncultivated hillsides, and the water in both cases is the usual brown colour common to Scottish burns. After passing through the hatchery, the water returns to the main stream and flows away to the sea.

The subsoil from which the streams draw their water is of granite covered with a thick layer of peat, and the volume of water flowing through the hatchery is about 300,000 gallons per hour.

The hatchery is situated in a hollow completely surrounded with hills one of which slopes down into the grounds, and in pre-war dsys was covered with spruce which has since been removed. The conditions of the water draining from this area being considerably altered in consoquence. 


\section{Contributions to the Biology of Freshooter Fiches}

At the base of this hill a large number of sphagnum bogs occur and the water passing through these bogs, though perfectly clear, has a very detrimental effect on fish-life as repeated experiments have shown.

It does not seem to make much difference whether the experiment is tried before or after a period of drought, or in spring or summer, tho result is the same, and yet not a yard separates the burn from the bogwater at some places.

Before deforestation of the hillside, the surface water was allowed to mix with that of the bum water running into the hatchery, but on account of its deadly character an extensive process of draining has been undertaken to prevent any of it reaching the water of the hatchery.

It may be a coincidence, but the altered character of the surface drainings since deforestation is very maded.

In a later paper I hope to deal more fully with this aphagnum water.

\section{Broow.}

The symptoms of this disease have already been mentioned. It can easily be removed by putting the fry into a solution of cornmon salt about 5 per cent. strength, but the bloom soon returns if the fish are put back into the same water from which they were drawn.

Microscopic examination of the bloom gives no clue as to its composition as it appears as a homogeneous mass of slime, no bacteria are present, nor do cultures from this alime give any positive results. Chemical investigations show it to be coegulated mucous due to the high acidity of the peat water at times, and the presence of vegetable toxins.

It has been stated that the hatchery is served by two streams, one draining a amall area and the other a larger one. Taking the acidity of the two streams after a period of normal steady weather, and using phenol phthalein as indicator and boiling the samples before titrating, the acidity of the two streams calculated as sulphuric acid give:

Stream from large area, 3-62 parts acid par 100,000

Stream from small area, 1-05 "\#,

It was found necesary to use $\mathrm{N} \mathrm{100,} \mathrm{N}=\mathrm{OH}$ and 200 c.c. quantities of water to get a good end point of the acidity.

It is found that the acidity varies considerably over long periods; given a period of settled weather the acidity rarely varies from the above, but after a storm (say two or three hours) the acidity drops quickly for about an hour, then rises quickly; within an hour I have known it rive 
to three or four times above the normal. The temperature may fall a degree or two but not to any marked extent.

After the acidity has risen it remains high for some hours and then very gradually comes down, taking often several days to get anywhere near the normal figure.

It is known by long experience that sudden changes in the weather are very trying for fish under artificial conditions and many young fish we lost on this account, older fish being able to withstand the changes much better than the young ones.

It has been found that the bloom makes its appearance immediately after this sudden rise in acidity, and from all experiments tried on the upot (and repeating as near as possible in glass tanks the condition of oudden rise in acidity, keeping the fish under observation all the time) it is found possible to produce artificially a somewhat similar appearance to what occurs at this hatchery, not forgetting that the water at the hatchery also contains a certain amount of vegetable matter in suspension and a certain number of vegetable toxins.

Dachnowsky in the Botanical Gazette, 1909, gives an account of vegetable toxins which are detrimental to animal and plant life and which occur in peat water at different times of the year.

Examination. of a large number of fish which have died through bloom always shows the mouth and gill covers extended to their widest extent with the tips of the gill filaments covered with a thick layer of cosgulated mucous, the stomach is invariably swollen, containing no food but varying amounts of coagulated mucous.

The first quarter of an inch of the intestine immediately following the pyloric end of the stomach is usually inflammed, due, I take it, to the high acidity of the contents of the stomach set up by the acid mucous.

Many experiments have been tried to effect a cure both on the spot and in the laboratory. Various reagents have been tried, but the most effective appears to be powdered lime, chalk, or lime water.

It has been found that causing the water to run through chalk filters, which hardens the water a little and brings down the acidity, is effectual; as is also the careful addition of lime to the water at a point where no free lime would be able to reach the hatchery. But the easiest and the most economical way has been by using lime water.

Calculating the average rate of flow and the highest acidity known to occur, it has been found possible by turning some of the ponds into lime-pits, and arranging that a certain amount of lime water flows in gradually to so regulate matters that this bloom no longer appears. 
The questions of the variation and composition of the dissolved gases are now under consideration, together with the composition of the water at varying seasons.

The conclusions to be drawn from this series of observations are:

1. That deforestation considerably alters the character of the water flowing from hillsides so far as fish life is concerned.

2. That the altered water in this instance has a very detrimental effect on fish life especially in the young stages.

3. That too high acidity of the peat water may cause the coagulation of the mucous on the gills, and sides of the fish, which may be fatal.

4. That a careful control and adjustment of the acidity of the water is necessary to ensure the non-appearance of this bloom, and lime water or chalk is the most effective.

(Received January 19th, 1922.) 